\title{
Animal waste utilization technology
}

\author{
Galia Kokieva ${ }^{1,}{ }^{*}$, Yurii Shaposhnikov ${ }^{2}$, Anastasia Spiridonova $^{3}$, and Zhanna Sivsheva ${ }^{4}$ \\ ${ }^{1}$ The Arctic State Agrotechnological University, 3, sh. Sergelyakhskoe 3 km, 677007, Yakutsk, the \\ Republic of Sakha (Yakutia), Russia \\ ${ }^{2}$ Altai State Technical University named after I. I. Polzunov. 46, Lenin Avenue, 656038, Barnaul, \\ Altai Krai, Russia \\ ${ }^{3}$ The North-Eastern Federal University named after M.K. Ammosov, 58, st.Belinskogo, 677007, \\ Yakutsk, the Republic of Sakha (Yakutia), Russia \\ ${ }^{4}$ Yakutsk Industrial Pedagogical College, 55, Dzerzhinskiy str., 677009, Yakutsk, the Republic of \\ Sakha (Yakutia), Russia
}

\begin{abstract}
The applicability of learned introduction of anaerobic digestion of animal waste will be obvious after a wide setting of afull-scale experiment and an across-the-board economic feasibility.However, yet today, basing on the domestic and abroad practice on biopowerdigesters engineering and operation, it can be argued that their use is economically advantageous than the traditional system. The obtained experience evidences thatthe cubicle housingof dairy cows is advanced. Milking operation is carried out in a special house, which ramps up milkquality, improves working conditions for milkmaids, and reduces labor costs. The problem of the animal waste impact on environment, especially on natural waters is acute. There is no summarized information about their distribution for fertilization and discharge.Not only liquid animal waste, but also silage sap causepollution. The Energy Program sets the task of widespread involvement of non-conventional energyin the country's energy balance. Biomass is of the great importance among such sources in the agro-industrial complex of the country.Anaerobicmethanoic digestion of animal waste allows evolving biogas - a valuable organic fertilizer with extra biological activityor protein-vitamin concentrates for feed supplementation. Such digestion of animal waste is an effective environmental action that provides its deodorization, reduction of soil and water pollution with repugnant substances and pathogenic microflora, atmospheric emissions (due to removal)
\end{abstract}

\section{Introduction}

A large amount of biomass energy in agriculture contributes to the continuous exploration and advanced technology development for its generation. These technologies include anaerobicmeth an egeneration. More homogeneous mass of the prepared mixture, the more intense and in the specified mode proceeds the process of biological fermentation. Based on these requirements, it has recently to use the use of screw workers in processing installations. For the implementation of anaerobic digestion of biomass, various technique

\footnotetext{
*Corresponding author: kokievagalia@mail.ru
} 
are developed in our country and abroad. Research and development in the field of disposal of liquid manure led to the creation of a new scientific direction - a complex biotransformation of waste of animal husbandry to obtain energy and feed protein. Experimental material accumulated in our institute and practical experience made it possible to create intensive two-phase processes and samples of equipment for such a manure processing. Thus, in the laboratory, it was possible to reduce the exposure of methane fermentation to 3 days and ensure the yield of a protein with $1 \mathrm{~m}^{3}$ of biogas to 300 $\mathrm{g}$ (according to the DEM) at a biomass density of $25 \mathrm{~g} / 1$. A blade paddle mixerhas been used for the animal wastedigestion.In order to stimulate gas formation, increase the mixing efficiency and prevent incrustation, a low depressionhasbeen hold in the gas cell of the reactor by constantly removing the nascent biogas in accordance with a preset sequence.During the unit startup period, the daily charge doses of the reactor amounted to 6 ... $8 \mathrm{~m}^{3}(4.8 \ldots 6.4 \%)$.

Then, after changing the full volume of the reactor, ithas been increased to $10 \%$ of the volume with automatic delivery of fractional portions 24 times a day.In general, the process of animal waste anaerobic digestion, controlled by temperature, biogas output, content of dry and organic substance in the charged and fermented biomass, $\mathrm{pH}$, volatile fatty acids and other technical parameters, has been satisfactory.However, the productivity of the bioreactor for gas output fluctuated greatly. The main reasonis the instability of the animal wastesupply, caused by the violations of its mucking out from the farm. The reason of thebiogasoutput loss is the breakdown of animal wastetransporting from the farm, the supply of a mass with high humidity. Upon resumption of the regular animal waste supply, the biogas output returns to normal quickly.

\section{Content}

The study of physical and microbiological indicators of manure, as well as their dependencies on the mode and processing methods made it possible to analyze the wellknown technological schemes and equipment for methane fermentation of organic waste and obtain feed additives from it; obtain experimental data on the dynamics of the methane fermentation processes and biosynthesis protein from biogas, amplitude-frequency, transfer and transient characteristics of these processes as control objects; determine the conditions for the intensification of each of the stages of microbiological processing of manure, including physical and biochemical preparations for fermentation and subsequent use of biogas. Develop the theoretical foundations for managing microbiological processing processes and optimization; Find rational principles for the construction of industrial devices for methane proceeding of the manure and biosynthesis of a protein that meet the conditions of agricultural production; Enough technical and economic prerequisites for the introduction of such devices.

At the same time, there are unresolved issues related to the theory and technique of conducting the processes of solid-phase, recycling and psychrofyl fermentation of organic waste, with the technological bases of the optimal control of liquid phase fermentation in anaerobic filtering mode, etc., which are of paramount importance to increase the efficiency of bioenergy attitudes and creating new generation reactors. To solve these problems, as well as the choice of the optimal number of options for these devices, it is necessary to complete the work on creating an anaerobic optimization model.

The solution to these problems will make it possible to significantly increase the performance of the equipment without increasing the volume of the reactor, the limited possibility of its transportation, as well as proceed to the development of high-performance bioreactors of a large volume. In this case, it is possible to ensure the efficient use of biogas plants on animal farms and complexes, the preservation of the block-modular principle of 
building equipment sets. Similar problems arise and in relation to utility runoff. In all cases, use to obtain a microbional gas substrate protein, in which there are no toxins, heavy metals and other harmful impurities, ensures high quality BVK, which cannot be achieved by any known conversion methods from organic waste.

In serious scientific and theoretical development and generalization, the issues of intensifying the biosynthesis of biogas protein processes are also needed in relation to lowtonnage agricultural installations, implementing biosynthesis processes under normal atmospheric pressure and without imaging technological oxygen.

During the methanoic fermentation, organic substances are mineralized in an anaerobic environment, in consequence of which the proportion of mineral nitrogen significantly increases by means of fragmentation of its related forms.Along with the prevention of direct losses of organic nutrients of the digested mass, its decontamination and devitalization (loss of weed age germinating ability) anddeodorization are achieved.The study of the physical and microbiological characteristics of animal waste, as well as their dependence on the condition and methods of digestionhas made it possible to analyze the known technological schemes and techniques for methanoic fermentation of organic waste and the production of fodder additives from it [3-7].

Figure 1 shows a diagram of a biostabilizer.

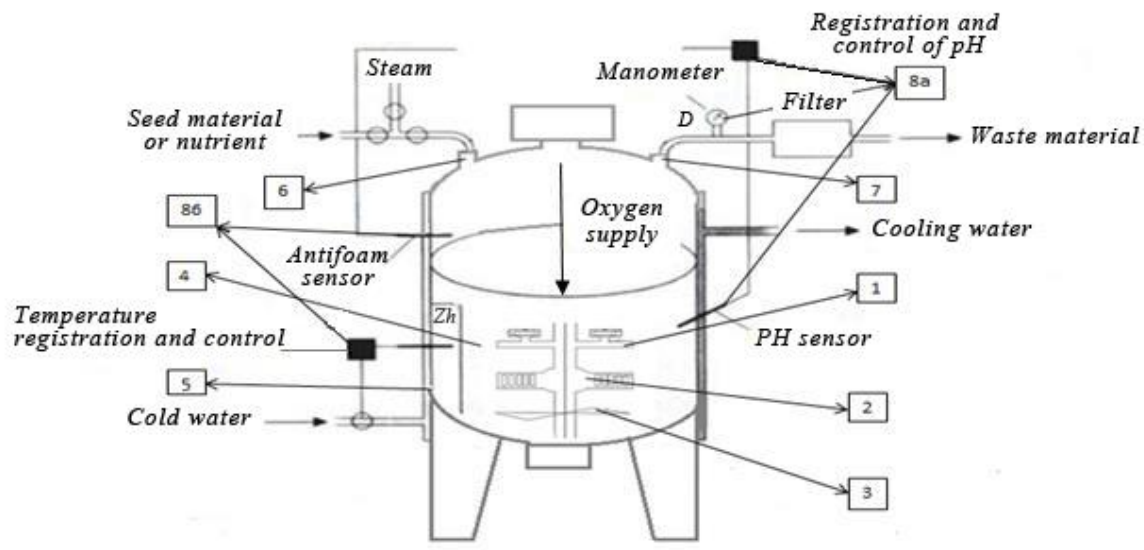

Fig.1. Schematic diagram of a laboratory fermentation unit: 1 - upper slurry agitator blade; 2 middle blade; 3 - lower blade; 4 - body; 5 - cooling jacket; 6 - nutritive substancesfeedline; 7 contaminated oxygen outlet pipeline with a pressure gauge; 8 - lower slurry agitator; 9- discharging branching pipe; 10 - base; 11,12 - branching pipes; 13 - reducer.

Periodic control of technological, biochemical and agrochemical indicators of animal waste hasbeen carried outat the main stages of digesting: in supplying from the farm, preliminary preparation in aheat-holding tank, at the outlet of the reactor. Sampleshas been taken in timeshifting in accordance with the periods of its passage along the technological chain [1114]. The residence time of the mass in the holding tank is $36 \mathrm{~h}$, in the reactor - 10 days. Table 1 shows the data on the content of organic substance in the fermented biomass; a decrease of $51 \%$ is observed.

The violent reaction of the medium reduces ( $\mathrm{pH}$ decreases from 7.46 to 7.26 ) in the holding tank and the concentration of methane precursors - volatile fatty acids - $45 \%$ increases, which indicates an active course of hydrolysis and acid production.It should be noted that the high concentration of VFA in the original mass has not lead, according to our observations, to a drop in the acidomedium and the suppression of the anaerobic process 
$[2,8]$.At the same time, some experts believe that the optimum VFA for the anaerobic process should be in the range of $600 \ldots 1500 \mathrm{mg} / 1[1,9,15]$.Large fluctuations in the mass humidity charged into the reactor, i.e. the uneven content of dry and organic substance has led to the instability of the process in the intensity of gas generation and in the depth of decomposition of organic substance.

\begin{tabular}{|c|c|c|c|}
\hline & $\begin{array}{c}\text { Original } \\
\text { animal waste }\end{array}$ & Matured & Fermented \\
\hline Absolutely dry substance, \% & 6.62 & 6.62 & 3.76 \\
\hline Organic substance, \% & 3.84 & 3.36 & 1.88 \\
\hline Volatilefattyacid, mg/l & 1830 & 2661.2 & 240.1 \\
\hline Acid exponent, $\mathrm{pH}$ & 7.46 & 7.26 & 7.74 \\
\hline
\end{tabular}

This also affected the quality of the fermented biomass - one of the finished products of digesting. The average values of the main technological indicators of the process, calculated by the average content of organic substance $(3.4 \%)$ in the charged biomass and the actual output of biogas $\left(150 \mathrm{~m}^{3} /\right.$ day) are given below:

\begin{tabular}{|l|c|}
\hline Daily supply, $\left.\% \mathbf{( m}^{\mathbf{3}}\right)$ & $\mathbf{1 0}(\mathbf{1 2 . 5})$ \\
\hline The content of organic matter in the original animal waste, $\mathrm{kg}$ & 420 \\
\hline Calculated decay of organic matter, \% $(\mathrm{kg})$ & $35(147)$ \\
\hline Real decay of organic matter, \% (kg) & $\begin{array}{c}46.7 \\
(194.8)\end{array}$ \\
\hline Biogas output, $\mathrm{m} 3 /$ day: & 113 \\
\hline Calculated & 150 \\
\hline Real & 1.32 \\
\hline Removal of biogas from $1 \mathrm{~m}^{3}$ of the reactor per day, $\mathrm{m}^{3}$ & \\
\hline
\end{tabular}

These data allow considering that with a charge equal to $10 \%$ of the reactor volume and organic substance decay degree of $47 \%$, up to $1.3 \mathrm{~m}^{3}$ of biogas per day can be obtained from $1 \mathrm{~m}^{3}$ of the reactor volume.

The process flow parameters differs at separate times of the year:

\begin{tabular}{|l|c|c|}
\hline & May & October \\
\hline Total Nitrogen & 0.0206 & 0.0285 \\
\hline Nitrogen ammonia & 0.00958 & 0.0160 \\
\hline Potassium & 0.0217 & 0.0343 \\
\hline Phosphorus & 0.0082 & 0.0147 \\
\hline Ratio: & & 12 \\
\hline Carbon-nitrogen $(\mathrm{C} / \mathrm{N})$ & 15 & 1.8 \\
\hline Total nitrogen -ammoniacal(N/(N-NH $)$ & 2.2 & \\
\hline
\end{tabular}


In digesting animal waste, depending on the depth of mineralization, the ratio of total nitrogen-ammonia and carbon-nitrogen decreases in accordance with the change of the nutrients content.However, they remain optimal for the biomass conversion and for the further effect of animal waste on the productivity of crops:

\begin{tabular}{|l|c|c|c|}
\hline Animal waste: & $\mathbf{C} / \mathbf{N}$ & $\mathbf{N} /\left(\mathbf{N}-\mathbf{N H}_{3}\right)$ & $\mathbf{C} /\left(\mathbf{N}-\mathbf{N H}_{3}\right)$ \\
\hline original & 12 & 1.8 & 20 \\
\hline matured & 13 & 1.8 & 23 \\
\hline fermented & 9 & 1.1 & 13 \\
\hline
\end{tabular}

During the conversion of materials in the reactor, the nitrogen concentration decreases mainly due to the protein forms with a simultaneous increase in the ammonia content by $6 \%$ in comparison with the original mass:

\begin{tabular}{|l|c|c|c|}
\hline Nitrogen: & Original & Matured & Fermented \\
\hline Total & 0.189 & 0.165 & 0.126 \\
\hline Ammoniacal & 0.106 & 0.094 & 0.113 \\
\hline Phosphorus & 0.097 & 0.087 & 0.077 \\
\hline Potassium & 0.227 & 0.213 & 0.264 \\
\hline Carbon & 2.300 & 2.150 & 1.420 \\
\hline
\end{tabular}

On a per unit basis of dry matter, an increase in ammoniacal nitrogen has been up to $46 \%$. The content of phosphorus and potassium in the fermented mass practically has not change.

Tests indicate that the main animal waste digesting is in the reactor: the amount of suspended substances in the fermented mass has been reduced by $40 \%$; in the holding tank - only by $4 \%$.

The fermentation has been experienced in a thermotolerant condition $\left(40^{\circ} \mathrm{C}\right)$, which leads to the best development of a group of microorganisms that occupy a natural ecological niche between the thermophilic and mesophilic groups [5,10]. The bacterial culture tests of total microbial contamination and the coli titer indicate that at a temperature of $+40^{\circ} \mathrm{C}$, a 10-day fermentation cycle and a high divided supply of the digested animal waste, a considerable reduction in sanitary indicators is not ensured. The total microbial contamination of the fermented mass is $1.43 * 10^{6}$, the original $-8.5 * 10^{6}$.

\section{Conclusion}

The methanoic fermentation of animal waste combined with the biogas digesting into feed protein based on controlled microbial synthesis is a new production process providing both energy and fodder additives. The course of microbial synthesis on per a volume unit of the output (biomass or metabolic products) will be the same or nearly the same in equipments of different scale. This technology makes it possible to implement fast process of substances bioconversion in a livestock enterprise in parallel with the traditional method of their revival in crop production, which provides real opportunities for founding livestock complexes in the form of non-waste industries that meet all the requirements of the economy and environmental safety.

The analysis of the physical characteristic of animal waste after fermentation has showed that the degree offully dry-ash-free substance decomposition is $22 \%$ at a daily 
charging dose of $4.5 \%$. The animal waste humidityand its ash content increase after fermentation. Itis explained by the partial dry matter discharge for biogasgeneration. In this case, it is possible to ensure the effective use of biogas digesters at livestock farms and complexes, and preserving themodular-assembly principleof constructing suites of equipment.

Thus, the methane junction of manure in combination with the processing of biogas released in the feed protein based on controlled microbial synthesis is a new production process, which ensures the production of both energy and feed additives. This technology allows you to implement an accelerated cycle of bioconversion of substances in parallel with the traditional path of their regeneration in crop production, which ensures the real possibilities of creating livestock complexes in the form of waste-free industries that meet all the requirements of the economy and environmental protection. Such an approach is all the more relevant that the main provisions of the energy program already at the first stage of its implementation provides for creating the necessary material and technical base for the widespread use of non-traditional energy sources, including the energy of organic biomass (manure, wildflow, etc.). In addition, the problem of waste disposal is very closely closed by another, increasingly exacerbating - environmental protection, which also requires intensive and rational recycling of animal waste.

\section{References}

1. V.P. Druzhanova, E.N. Kobyakova, Collection of scientific papers on the materials from International Scientific-Practical Conference "Science and education in the XXI century" (Tambov), 57-61 (2014)

2. R.Y. Dyganova, G.A. Mazitova, Academic Bulletin ELPIT, 5, 11-17 (2020)

3. T.A. Gamm, S.V. Volokhov, Science and Culture: Materials of the All-Russian Scientific and Methodological Conference (with international participation), Orenburg, January 23-25, 2020. - Orenburg: Orenburg State University, 834-836 (2020)

4. A.E. Katashova, A.I. Dorokhova, a collection of articles of the III International Scientific and Practical Conference, Penza, November 30, 2020. - Penza: Penza State Agrarian University, 41-44 (2020)

5. V.D. Khmyrov, V.B. Kudenko, B.S. Trufanov, Agrarian science,11, 30-32 (2011)

6. G.E. Kokieva, Scientific and technical bulletin of the Volga region, 3, 137-139 (2014)

7. G.E. Kokieva, Scientific and technical bulletin of the Volga region,4, 123-125 (2014)

8. M.M. Kolosova, Achievements of science and technology of the agro-industrial complex, 5 (31), 57-59 (2017)

9. B.M. Mirzaev, Materials of the international scientific-practical conference of young Scientists, Molodezhny settlement, March 26-27 - p. Molodezhny: Irkutsk State Agrarian University named after A.A. Ezhevsky, 271-275 (2020)

10. M. Pilzer, Engineering protection, 1 (6), 12-17 (2015)

11. P.P. Protsenko, T.A. Nikolaeva, Bulletin of the Amur State University: Natural and Economic Sciences, 89, 82-87 (2020) DOI 10.22250/jasu.21

12. A.V. Ryazanov, A.V. Mozharov, A.N. Zavershinsky, International Research Journal, 6-2 (60), 127-129 (2017) DOI 10.23670/IRJ.2017.60.046 
13. V.N. Sharifullin, A.I. Boyarinov, A.M. Gumerov, Mass transfer processes and chemical equipment's technology (Kazan), 17-18 (2016)

14. I.M. Sukhanova, R.R. Gazizov, M.K. BikkininaL, I.A. Yapparov, Agrochemical Herald, 6, 26-28 (2015)

15. V.T. Vodyannikov, Economics of Agricultural and Processing Enterprises, 7, 26-31 (2020) 